\title{
Effects of Foliar Application of Micronutrients on Agronomic Traits of Beet Cv. Sonja under Dsa (Hot Summer Continental) Climatic conditions of Naqadeh Iran
}

\author{
Amir Rahimi ${ }^{1, a, *}$, Sina Siavash Moghaddam ${ }^{1, b}$, Seyyed Ali Noorhosseini ${ }^{2, c}$, Mortaza Hajyzadeh $^{3, d}$ \\ ${ }^{I}$ Department of Agronomy, Faculty of Agriculture, Urmia University, Urmia, Iran \\ ${ }^{2}$ Department of Agriculture and Natural Resources, Payame Noor University, Tehran, Iran. \\ ${ }^{3}$ Department of Field Crops, Faculty of Agriculture and Natural Sciences, Uşak University, 64000 Uşak, Turkey.
}

${ }^{*}$ Corresponding author

\begin{tabular}{|c|c|}
\hline A R T I C LE I N F O & A B S T R A C T \\
\hline $\begin{array}{l}\text { Received : 24/06/2018 } \\
\text { Accepted : 15/08/2018 }\end{array}$ & $\begin{array}{l}\text { Plants need different macro and micro nutrient elements to grow and reproduce. Their malnutrition } \\
\text { results in unhealthy growth. The soils of Naqadeh area, Iran are deficient in micronutrient elements. } \\
\text { The aim of the study was to evaluate the effects of micronutrients application on some qualitative } \\
\text { and quantitative parameters of economically important monogerm sugar beet cv. Sonja. The plants } \\
\text { were foliar sprayed with iron, boron, zinc, and manganese. The studied traits were potassium, } \\
\text { sodium, nitrogen, extraction coefficient, sugar percent, recoverable sugar, alkalinity, molasses, root } \\
\text { yield, and white sugar recovery yield. The effect of micronutrients was significant on all studied } \\
\text { traits. The highest extraction coefficient of } 89.31 \text { was related to the foliar application of iron (Fe) } \\
\text { and the highest recoverable sugar percent }(16.91 \%) \text { was obtained from } \mathrm{Zn} \text { application. Also, the } \\
\left.\text { highest mean root yield ( } 74.120 \mathrm{t} \mathrm{ha}^{-1}\right) \text { and white sugar yield }\left(12.137 \mathrm{tha}^{-1}\right) \text { were noted after foliar } \\
\text { treatments of boron (B) and } \mathrm{Fe} \text {, respectively. }\end{array}$ \\
\hline
\end{tabular}

Sugar beet

Foliar spray

Yield

Hot summer continental climate

Türk Tarım - Gıda Bilim ve Teknoloji Dergisi 7(6): 828-832, 2019

\section{Mikrobesin Maddelerin Şeker Pancarın Sonja Çeşidinde Yapraktan Uygulamasının Tarımsal Özellikleri Üzerine Etkileri}

\begin{tabular}{l} 
M A K A L E B İ L G \\
\hline Araştırma Makalesi \\
\\
Geliş $\quad: 24 / 06 / 2018$ \\
Kabul $\quad: 15 / 08 / 2018$
\end{tabular}

Anahtar Kelimeler:

Mikro besinler

Şeker pancarı

Yaprak spreyi

Verim

Sicak yaz iklimi

\section{ÖZ}

Bitkiler, büyüme ve gelişimleri için farklı makro ve mikro besin elementlerine ihtiyaç duymaktadırlar. Yetersiz beslenme durumları sağlıssı büyümeleri ile sonuçlanmaktadır. İran'ın Nekede bölgesinin toprakları, mikro besin elementleri bakımından yetersiz olmaktadır. $\mathrm{Bu}$ çalışmada, Sonja çeşidinde mikro besin maddelerinin yapraktan uygulanması sonucunda kalitatif ve verim özellikleri üzerine etkisi incelenmiştir. Bitki yapraklarına demir, bor, çinko ve manganez püskürtülmüştür. Potasyum, sodyum, azot, ekstraksiyon katsayısı, şeker yüzdesi, arınabilen şeker yüzdesi, alkalinite, melas, kök verimi ve beyaz şeker verimi parametreleri incelenmiştir. Çalışılan tüm özelliklerde, mikro besin maddelerinin etkisi önemli bulunmuştur. En yüksek ekstraksiyon katsayıs1 89,31 ile demir (Fe) uygulamasından ve en yüksek elde edilen şeker yüzdesi $(\% 16,91)$ çinko (Zn) uygulamasından elde edilmiştir. Ayrıca en yüksek ortalama kök (74,120 ton ha-1) ve beyaz şeker verimleri $(12,137 \pm$ ha-1) ise sirasıyla bor ve demirin yapraklara uygulanması sonucunda elde edilmiştir. 


\section{Introduction}

Sugar beet (Beta vulgaris L.) is a biennial, diploid $(2 \mathrm{n}=18)$ plant which is the main source of sucrose and income for farmers and has a considerable role in gross domestic production (GDP) of Iran. Over $30 \%$ of world soils suffer from the deficiency of one or more micronutrients, a trend which is deteriorating (Sillanpaa, 1982), with the passage of time. The share of micronutrients in total fertilizer consumption is about 2$4 \%$ in developed countries (Masri and Hamza, 2015). There are numerous reports about the role of micronutrients in enzymatic responses, plant metabolism and assimilation of carbon, nitrogen and different compounds, sugar translocation, cellular division, water regulation, conductivity, and consequently, higher photosynthetic capacity and productivity of the plants (Shiemshi, 2007). The best approach to realize this objective and also, earn foreign exchange is to increase production per unit area and improve crop quality (Run and Johnson, 1999; Masri and Hamza, 2015). Plants require some nutrients for optimum growth, among which trace elements like Fe, B, boron (B), iron (Fe), manganese $(\mathrm{Mn})$, magnezyum $(\mathrm{Mg})$ and molibden (Mo) are needed (Fajrya, 1998); but, their deficiencies in soil can affect the performance of macronutrients (Xue et al., 2014).

Deficiency is widely common in sugar beet growing regions throughout the world and its symptoms are almost similar in all countries. The symptoms of this deficiency are usually visible on plants growing on soils with B content of less than $0.5 \mathrm{mg} \mathrm{kg}-1$ (Armin and Asgharipour, 2012) B, Copper $(\mathrm{Cu}), \mathrm{Mg}, \mathrm{Mn}$, and zinc $(\mathrm{Zn})$ are important nutrient elements for the growth and develoment of sugar beet. Micronutrient elements such as $\mathrm{B}, \mathrm{Cu}, \mathrm{Mn}$, and $\mathrm{Zn}$ have important role in development and yield improvement of crop plants (Ziaeian and Malakouti, 2001) however, foliar applications of micro nutrient fertilizers are considered more appropriate (Kristek et al., 2006; Çelik et al., 2010).

Foliar spray of crops can supplement soil application of nutrients. Micronutrients application in case of their deficiencies, especially by spray, can improve the yield and yield components of safflower and other crop plants (Lewis and McFarlane, 1986; Arnon, 2001; Fernandez et al., 2004). According to Erdal et al. (2004), Fe spray increased growth and metabolism of strawberries. Teixeira et al. (2004), reported that foliar application of $\mathrm{Zn}$ and $\mathrm{Mn}$ increased dry matter by 18 and $32 \%$ as compared to control, treatments respectively. Lin (1996), reported that soybean grain yield was sharply increased with foliar spray and soil application of Mn and that foliar application was more effective than soil application. Masri and Hamza (2015) sprayed sugar beet zinc (Zn) + Manganese $(\mathrm{Mn})+$ Iron $(\mathrm{Fe})+$ Boron $(\mathrm{B})$ and noted positive effect of foliar application on sugar beet root yield.

There is no previous study reporting about the effect of micronutrients on some properties of sugar beet in the region. The study aimed to evaluate the effects of micronutrients (Fe, $\mathrm{Zn}, \mathrm{B}$, and $\mathrm{Mn}$ ) spray on some qualitative and quantitative parameters of sugar beet (cv. Sonja) under Naqadeh condition (Elevation: 4298 feet, Latitude: 36 57N, Longitude: 045 23E).

\section{Materials and Methods}

The study was carried out in experimental farm of Naqadeh Sugar Factory "Dsa". (Hot Summer Continental Climate) of Naqadeh Elevation: 4298 feet, Latitude: 36 $57 N$, Longitude: 045 23E. Soil physico-chemical properties were measured on soil samples taken at the depth of 0-30 $\mathrm{cm}$. The experimental treatments included foliar spray of trace elements $-\mathrm{B}, \mathrm{Fe}, \mathrm{Mn}$, and $\mathrm{Zn}-$ at five levels and no trace element application as control. The experimental plots consisted of $4 \times 4 \mathrm{~m}^{2}$ composed of eight sugar beet sowing rows on ridges with inter-row spacing of $50 \mathrm{~cm}$ and inter-plant spacing of $20 \mathrm{~cm}$. After preparation, the plots were manually sown by wet planting in rows on April 3, 2012. The seeds were provided by the Naqadeh Sugar beet factory with $98 \%$ viability and $99 \%$ purity. The plots were thinned and weeded twice at 4-6-leaf stage and 6-8-leaf stage. Agronomic operations like weeds control, crust breaking, irrigation, etc. were performed manually. The plots were sprayed with micronutrients in two stages using a fog machine, for which spray was dissolved in water at 2weeks interval during vegetative period in early hours of the day when it was cool and there was no wind. The micronutrient fertilizers $\mathrm{Fe}, \mathrm{Zn}, \mathrm{B}$, and $\mathrm{Mn}$ at the rates of $1,1,2$, and $31 \mathrm{ha}^{-1}$ respectively were procured from a Company in Mashhad and applied according to producer recommendation. At harvest time, all plants were harvested after eliminating two marginal rows at $0.5 \mathrm{~m}$ from both ends of the plots. The sugar content and impurities of sugar beets including $\mathrm{Na}, \mathrm{K}$ and amino-N were estimated by flame photometry in Sugar Technology Laboratory of Sugar beet Seed Institute, Karaj to estimate the differences among harvest periods in sugar percentage, $\mathrm{N}$ percentage, $\mathrm{K}$ and $\mathrm{Na}$. The detached roots from the shoot were rinsed and turned into root pulp by sampling device. Then, their qualitative parameters were determined by betalyser (model D-3016) and flame photometer. Sugar percent and impurities of roots (amino $\mathrm{N}, \mathrm{K}$ and $\mathrm{Na}$ contents) were measured by betalyser and flame photometer (Kunz, 2004). Molasses percent was calculated by Equation (1) (Dutton and Bowler, 1984).

$$
\operatorname{MS}(\%)=0.343(\mathrm{~K}+\mathrm{Na})+0.094(\alpha-\text { amino }-\mathrm{N})-0.29
$$

Where, MS represents molasses, and $\mathrm{K}, \mathrm{Na}$, and amino $\mathrm{N}$ are expressed in meq $100 \mathrm{~g}^{-1}$ sugar beet root.

White sugar percent or recoverable sugar percent was estimated as the difference in sugar percent and molasses percent using Equation (2) (Shoae et al., 2014).

$$
\operatorname{ESC}(\%)=\operatorname{SC}(\%)-\mathrm{MS}(\%)
$$

Where, WSC represents recoverable sugar content, SC represents sugar percent, and MS represents molasses percent.

Sugar percent, or sugar content, includes recoverable sugar percent plus sugar percent of molasses. The sucrose content was measured by polarimetry method. The method is based on the deviation percent of polarized light. To measure qualitative parameters of the root, root pulp and lead acetate were mixed with the ratio of $26 \mathrm{~g}$ pulp and $177.7 \mathrm{~cm}^{3}$ lead acetate by automatic mixers. 
Then, it was infiltrated by filter paper No. 42 and the extract was taken. Afterwards, sugar percent was determined by polarimetry method (Kunz, 2004).

Alkalinity shows that the juice is base and is of crucial importance in carbonation in terms of juice buffering capacity, $\mathrm{CO} 2$ uptake, and $\mathrm{Ca}$ removal, so that the juice $\mathrm{pH}$ should not be less than a specific limit after dilute juice stage; otherwise, acidic inversion happens and sucrose turn into invert sugar. Alkalinity of the studied samples was calculated by Equation (3) (Aazam et al., 2016).

$$
\text { Alkalinity }=\mathrm{Na}+\mathrm{K} / \mathrm{N}
$$

$\mathrm{K}$ and Na content of root pulp extract was measured in terms of meq per $100 \mathrm{~g}$ root pulp by flame photometer which compares the emission spectrum of the sample with that of lithium. Amino-N percent was estimated by betalyser. The device mixes the extract and copper reagent with equal ratios and monitors the color change, comparing it with the standards. It expresses amino-N percent in terms of meq per $100 \mathrm{~g}$ root pulp (Kunz, 2004).

The soil charachteristics of the experimental area are given in Table 1. The results show that the soil had 9.1, $\mathrm{kg} / \mathrm{da} \mathrm{P}_{2} \mathrm{O}_{5}, 0.70 \%$ organic matter, $0.06 \%$ Total $\mathrm{N}, 23.0 \%$ TNV, 55\% SP, electrical conductivityof $0.721 \mathrm{dS} / \mathrm{m}, 39 \%$ clay, $43 \%$ silt, $18 \%$ sand, oH of 7.81 , Fe of $8.71 \mathrm{mg} \mathrm{kg-1,}$ $\mathrm{Zn}$ of $1.1 \mathrm{mg} \mathrm{kg}-1, \mathrm{~B}$ of $0.33 \mathrm{mg} \mathrm{kg}-1$ and $\mathrm{Mn}$ of 11.65 mg kg-1 (Table 1).

Table 1 Results of soil analysis

\begin{tabular}{l|r}
\multicolumn{1}{c}{ Nutrient and soil charachterisitics } & Results \\
\hline $\mathrm{P}_{2} \mathrm{O}_{5}(\mathrm{~kg} / \mathrm{da})$ & 9.1 \\
$\mathrm{~K}_{2} \mathrm{O}(\mathrm{kg} / \mathrm{da})$ & 379 \\
Organic matter $(\%)$ & 0.70 \\
Total N (\%) & 0.06 \\
TNV (\%) & 23.0 \\
$\mathrm{SP}(\%)$ & 55 \\
$\mathrm{EC}(\mathrm{dS} / \mathrm{m})$ & 0.721 \\
$\mathrm{Clay}(\%)$ & 39 \\
$\mathrm{Silt}(\%)$ & 43 \\
Sand $(\%)$ & 18 \\
$\mathrm{pH}$ & 7.81 \\
Fe $\left(\mathrm{mg} \mathrm{kg}^{-1}\right)$ & 8.17 \\
$\mathrm{Zn}\left(\mathrm{mg} \mathrm{kg}^{-1}\right)$ & 1.1 \\
$\mathrm{~B}\left(\mathrm{mg} \mathrm{kg}^{-1}\right)$ & 0.33 \\
$\mathrm{Mn}\left(\mathrm{mg} \mathrm{kg}^{-1}\right)$ & 11.65 \\
\hline
\end{tabular}

\section{Results and Discussion}

Results of analysis of variance (Table 2) showed significant differences among micronutrients application and control in extraction coefficient, sugar percent, sodium, nitrogen, recoverable sugar percent, alkalinity, molasses, potassium, and root yield $(\mathrm{P}<0.01)$ and white sugar yield at the $5 \%$ probability level.

\section{Sugar Percent}

Foliar application of micronutrients significantly influenced sugar percent $(\mathrm{P}<0.01-$ Table 2). Means comparison revealed that the highest sugar percent of
$18.94 \%$ was related to $\mathrm{Zn}$ application, but the lowest one $(18.11 \%$ ) was observed in B treatment (Table 3 ).

\section{Extraction Coefficient}

Extraction coefficient was significantly influenced by the foliar application of micronutrients $(\mathrm{P}<0.01$-Table 2$)$. According to means comparison, Fe application resulted in the highest extraction coefficient of $89.31 \%$, whilst the lowest coefficient $(86.53 \%)$ was observed in control. No significant differences were observed among $\mathrm{Fe}, \mathrm{B}$ and $\mathrm{Zn}$ treatments, but it showed significant differences with control and $\mathrm{Mn}$ application (Table 3). Foliar application of $\mathrm{Fe}$ improved growth and production of sugar beets (Fernandez et al. 2004). As well, it has been reported that $\mathrm{Zn}$ application improved sugar beet root yield significantly (Masri and Hamza 2015).

\section{Recoverable Sugar Percent}

It was observed that the application of different micronutrients caused significant differences in recoverable sugar percent $(\mathrm{P}<0.01$-Table 2$)$, sugar percent of $16.91 \%$ related to the treatment of $\mathrm{Zn}$ and the lowest one $(16.16 \%)$ to the treatment of Mn (Table 3).

\section{Molasses Percent}

Molasses percent was significantly impacted by the application of micronutrients $(\mathrm{P}<0.01$-Table 2$)$. The highest and lowest molasses percents were obtained from control and B application (2.56 and 1.92\%), respectively. There were no significant differences among Fe, B and Zn treatments (Table 3).

\section{Potassium}

The impact of micronutrients was significant on sugar beet potassium content $(\mathrm{P}<0.01-$ Table 2). Control exhibited the highest $\mathrm{K}$ content of $4.26 \mathrm{mg} \mathrm{kg}^{-1}$ and $\mathrm{B}$ treatment showed the lowest one of $3.64 \mathrm{mg} \mathrm{kg}^{-1}$ (Table 3).

\section{Sodium}

Micronutrients changed sugar beet sodium content significantly $(\mathrm{P}<0.01$-Table 2$)$. The highest and lowest $\mathrm{Na}$ contents were observed in control $\left(1.77 \mathrm{mg} \mathrm{kg}^{-1}\right)$ and $\mathrm{Fe}$ treatment $\left(0.83 \mathrm{mg} \mathrm{kg}^{-1}\right)$, respectively (Table 3$)$.

\section{Nitrogen}

The effect of micronutrients was significant $(\mathrm{P}<0.01)$ on sugar beet nitrogen content (Table 2). Control and B treatment showed the highest and lowest $\mathrm{N}$ content (2.24 and $1.01 \mathrm{mg} \mathrm{kg}^{-1}$ ), respectively (Table 3 ).

\section{Alkalinity}

Alkalinity was significantly $\quad(\mathrm{P}<0.01-$ Table 2) influenced by micronutrients $\mathrm{B}$ treatment and control were associated with the highest and lowest alkalinity (4.5 and 2.66), respectively (Table 3 ).

\section{Root and White Sugar Yield}

The effect of micronutrients was significant on root yield $(\mathrm{P}<0.01)$ and white sugar yield $(\mathrm{P}<0.05$-Table 2$)$. The highest mean root yield $\left(74.120 \mathrm{t} \mathrm{ha}^{-1}\right)$ and white sugar yield (12.137 $\left.\mathrm{t} \mathrm{ha}^{-1}\right)$ were observed in $\mathrm{B}$ and $\mathrm{Fe}$ treatments, respectively (Table 3 ). 
Table 2 Analysis of variance for the effect of different elements on qualitative and quantitative traits of sugar beet cv. Sonja under Dsa (Hot Summer Continental) Climatic conditions of Naqadeh Iran

\begin{tabular}{|c|c|c|c|c|c|c|c|c|c|c|c|c|}
\hline \multirow{2}{*}{ SOV } & \multirow{2}{*}{ Df } & \multicolumn{11}{|c|}{ Means of squares } \\
\hline & & $\mathrm{K}$ & $\mathrm{Na}$ & $\mathrm{N}$ & $\mathrm{Al}$ & $S$ & $\mathrm{EC}$ & $\mathrm{RS}$ & $\mathrm{M}$ & RY & SY & WSY \\
\hline Block & 3 & 0.001 & 0.006 & 0.02 & $0.01^{\mathrm{ns}}$ & 0.08 & $0.18^{*}$ & $0.08^{\mathrm{ns}}$ & $0.002^{\mathrm{ns}}$ & 19.099 & 0.544 & 0.390 \\
\hline Micronutrie & 4 & ns & ns & ns & $1.79^{* *}$ & $\mathrm{~ns}$ & $5.59^{* *}$ & $0.43^{* *}$ & & $* *$ & $* *$ & ns \\
\hline Nts & 1 & 0.25 & 0.58 & 0.96 & 0.05 & 0.49 & 0.04 & 0.04 & $0.28^{* *}$ & 8.460 & 0.021 & 0.14 \\
\hline Experiment & 2 & $* *$ & $* *$ & $* *$ & & $* *$ & & & 0.002 & $* *$ & ns & $0^{*}$ \\
\hline Al error & & 0.005 & 0.003 & 0.03 & & 0.04 & & & & 1.062 & 0.071 & 0.068 \\
\hline C.V. $(\%)$ & & 1.94 & 5.29 & 12.51 & 6.3 & 1.11 & 0.24 & 1.32 & 2.13 & 1.42 & 1.98 & 2.19 \\
\hline
\end{tabular}

Table 3 Means comparison for the effect of different elements on qualitative and quantitative traits of sugar beet cv. Sonja under Dsa (Hot Summer Continental) Climatic conditions of Naqadeh Iran

\begin{tabular}{l|ccccccccccc}
\hline \multirow{2}{*}{$\mathrm{T}$} & $\mathrm{K}$ & $\mathrm{Na}$ & $\mathrm{N}$ & $\mathrm{Al}$ & $\mathrm{S}$ & $\mathrm{EC}$ & $\mathrm{RS}$ & $\mathrm{M}$ & $\mathrm{RY}$ & $\mathrm{SY}$ & WSY \\
\cline { 2 - 11 } & $\mathrm{ppm}$ & $\mathrm{ppm}$ & $\mathrm{ppm}$ & - & $\%$ & $\%$ & $\%$ & $\%$ & $\mathrm{tha}^{-1}$ & $\mathrm{t} \mathrm{ha}$ & $\mathrm{th} \mathrm{h}^{-1}$ \\
\hline Control & $4.26^{\mathrm{a}}$ & $1.77^{\mathrm{a}}$ & $2.24^{\mathrm{a}}$ & $2.66^{\mathrm{c}}$ & $18.88^{\mathrm{ab}}$ & $86.53^{\mathrm{c}}$ & $16.26^{\mathrm{bc}}$ & $2.56^{\mathrm{a}}$ & $71.472^{\mathrm{b}}$ & $13.495^{\mathrm{a}}$ & $11.630^{\mathrm{b}}$ \\
Zinc & $3.73^{\mathrm{c}}$ & $0.94^{\mathrm{c}}$ & $1.2^{\mathrm{bc}}$ & $3.9^{\mathrm{b}}$ & $18.94^{\mathrm{a}}$ & $89.25^{\mathrm{a}}$ & $16.91^{\mathrm{a}}$ & $1.98^{\mathrm{c}}$ & $70.915^{\mathrm{b}}$ & $13.430^{\mathrm{a}}$ & $11.995^{\mathrm{ab}}$ \\
Iron & $3.71^{\mathrm{c}}$ & $0.83^{\mathrm{d}}$ & $1.16^{\mathrm{bc}}$ & $3.92^{\mathrm{b}}$ & $18.56^{\mathrm{bc}}$ & $89.31^{\mathrm{a}}$ & $16.6^{\mathrm{ab}}$ & $1.93^{\mathrm{c}}$ & $73.097^{\mathrm{a}}$ & $13.572^{\mathrm{a}}$ & $12.137^{\mathrm{a}}$ \\
Manganese & $3.95^{\mathrm{b}}$ & $1.1^{\mathrm{b}}$ & $1.4^{\mathrm{b}}$ & $3.66^{\mathrm{b}}$ & $18.32^{\mathrm{cd}}$ & $88.12^{\mathrm{b}}$ & $16.16^{\mathrm{c}}$ & $2.1^{\mathrm{b}}$ & $73.963^{\mathrm{a}}$ & $13.565^{\mathrm{a}}$ & $11.952^{\mathrm{ab}}$ \\
Boron & $3.64^{\mathrm{c}}$ & $0.9^{\mathrm{cd}}$ & $1.01^{\mathrm{c}}$ & $4.5^{\mathrm{a}}$ & $18.11^{\mathrm{d}}$ & $89.11^{\mathrm{a}}$ & $16.17^{\mathrm{c}}$ & $1.92^{\mathrm{c}}$ & $74.120^{\mathrm{a}}$ & $13.420^{\mathrm{a}}$ & $11.982^{\mathrm{ab}}$ \\
\hline
\end{tabular}

T: Treatment; Al: Alkalinity; S: Sugar (\%); EC: Extraction coefficient; RS: Recoverable sugar (\%); M: Molasses (\%); RY: Root yield; SY: Sugar yield; WSY: White sugar yield; Means followed with similar letter(s) in each column had no significant differences $(\mathrm{P}<0.05)$ according to Duncan Test.

\section{Discussion}

Micronutrients have a significant effect on the extraction coficient and the recoverable sugar percentage. It seems that the better availability of micronutrient elements leads to more effective absorption and greater availability of the nutrients and elements (Marschner, 1995). Fertilizer and physiological growth stages of a plant has significant positive interactions (Mandal et al., 2007). In similar studies, foliar application of micronutrients in different ontogenetic stages of plant growth were significant for important traits including plant yield (Sultana et al., 2016). Therefore, it very important to optimize fertilizer efficiency for appropriate growth of a plant.

Micronutrients increase the yield and essential oil through the effect of manganese on photosynthesis and assimilates (Ziaeian and Malakouti, 2001). Also, plant yield is affected by application of micro nutrients (Mandal et al., 2007). Enhancing non-sugar compounds in the sugar beet root extract prevents the sugar crystallization process in sugar beet factories and leads to an increase in the percentage of molasses sugar, which is in fact is an indicator for determining the decline in sugar production. The results revealed that the effect of drought stress in this cultivars on the given trait were not significant. The findings of the current study confirms that drought stress at the end of the growth period of sugar beet increased the amount of impurities of the root compounds and thus reduced the extraction efficiency.

\section{Conclusion}

The application of micronutrients influenced all studied traits significantly. The highest extraction coefficient was related to Fe foliar spray and the highest recoverable sugar percent was related to $\mathrm{Zn}$ application.
Root yield and white sugar yield were found highest in the treatments of $\mathrm{B}$ and $\mathrm{Fe}$, respectively. Thus, the application of micronutrients may improve photosynthesis efficiency and leaf area duration of sugar beets and also, increase metabolic activities resulting in yield or sugar percent gain.

\section{References}

Aarabi A, Mizani M, Honarvar M, Faghihian H, Gerami A. 2016. Extraction of ferulic acid from sugar beet pulp by alkaline hydrolysis and organic solvent methods. Journal of Food Measurement and Characterization, 10 (1): 42-47.

Armin M, Asgharipour M. 2012. Effect of Time and Concentration of Boron Foliar Application on Yield and Quality of Sugar Beet. American-Eurasian J. Agric. \& Environ. Sci., 12 (4): 444-448, ISSN 1818-6769.

Arnon DI. 2001. Criterion of essentiality of inorganic micronutrients. In W. D. McElroy, \& B. Glass (Eds.), Trace elements in plant physiology. Waltham, Massachusetts: Cronica Botanica.

Çelik H, Katkat AV, Aşık BB, Turan MA. 2010. Effect of foliar-applied humic acid to dry weight and mineral nutrient uptake of maize under calcareous soil conditions. Commun Soil Sci Plant Ana. 42(1): 29-38.

Dutton JV, Bowler G. 1984. Money is still being wasted on nitrogen fertilizer. Brit. Sugar Beet Rev.

Erdal I, Kepenek K, Kizilgoz, I. 2004. Effect of foliar iron applications at different growth stages on iron and some nutrient concentrations in strawberry cultivars. Turk J Agric For 28: 421-427.

Fajrya NK. 1998. Increase crop yield. Translation Dezfuli Abolhassan Hashemi, a small change, Mohammad masons First, Mashhad University Jihad (In persian)

Fernandez V, Winkelmann G, Elbert G. 2004. Iron supply to sugar beet plants through foliar application of iron citrate and ferric dimerum acid. Physiol. Planta. DOI10.1111/j.1399-3054.2004.00405.x, 122 (3): 380-385. 
Kristek A, Stojić B, Kristek S. 2006. Effect of the foliar boron fertilization on sugar beet root yield and quality. Agriculture. 12: 22-26.

Kunz M. 2004. Sugar analysis. Beet. The international commission for uniform methods of sugar analysis (ICUMSA), General Subject 6: 110-117.

Lewis DC, McFarlane JD. 1986. Effect of foliar applied manganese on the growth of safflower (Carthamus tinctorius L.) and the diagnosis of manganese deficiency by plant tissue and seed analysis. Australian Journal of Agricultural Research, 37: 567-572. DOI10.1071/AR9860567.

Lin CH. 1996. Methods and sources of applied manganese on converted low-manganese paddy field for soybean. Bulletin of The Hualien District Agricultural Improvement Station No.3:95-96.

Mandal A, Patra AK, Singh D, Swarup A, Masto RE. 2007. Effect of long-term application of manure and fertilizer on biological and biochemical activities in soil during crop development stages. Bioresour. Technol. 98: 3585-3592.

Marschner H. 1995. Mineral Nutrition of Higher Plants. (2nd Ed), Academic press, London. ISBN 9780123849052

Masri MI, Hamza M. 2015. Influence of Foliar Application with Micronutrients on Productivity of Three Sugar Beet Cultivars under Drip Irrigation in Sandy Soils World Journal $\begin{array}{llll}\text { of Agricultural Sciences } 11 & \text { (2): 55-61. DOI: }\end{array}$ 10.5829/idosi.wjas.2015.11.2.1846.

Run WR, Johnson GV. 1999. Improving nitrogen use efficiency for cereal production. Agronomy Journal, 91: 357-363.
Shiemshi D. 2007. Leaf chlorosis and stomatal aperture. New Phytologist 166: 455-461

Shoae MS, Habibi D, Taleghani DF, Paknejad F, Kashani A. (2014) Response of Autumn Sugar Beet to Foliar Application of Paclobutrazol in Karaj Region. Appl. Environ. Biol. Sci. 51, 12-17, 4(6): 180-185, ISSN: 20904274.

Sillanpaa M. 1982. Micronutrients and nutrient status of soils: A Global Study. FAO Soil Bulletin No. 48, Food and Agriculture Organization, Rome.

Sultana H, Naser M, Akhter S, Begum RA. 2016. Effectiveness of soil and foliar applications of zinc and boron on the yield of tomato S. Bangladesh J. Agril. Res. 41(3): 411-418, ISSN 0258-7122 (Print), 2408-8293 (Online)

Teixeira IR, Borem A, de Andrade Araujo GA, Lucio R, Fontes F. 2004. Manganese and zinc leaf application on common bean on a cerrado soil. Sci. Agric. (Piracicaba, Braz.), 61 (1): 77-81.

Xue Y, Yue S, Zhang W, Liu D, Cui Z, Chen X, Ye Y, Zou C. 2014. Zinc, Iron, Manganese and Copper Uptake Requirement in Response to Nitrogen Supply and the Increased Grain Yield of Summer Maize. PLoS One. (4): e93895. doi: 10.1371/journal.pone.0093895.

Ziaeian AH, Malakouti MJ. 2001. Effect of Fe, Mn, $\mathrm{Zn}$ and $\mathrm{Cu}$ fertilization on yield and grain quality of wheat in the calcareous soils of Iran: In W. J.Horst, Schenk, M. K., Buerkert et al. (eds) Plant Nutrition Food Security and Sustainability of Agroecosystems. Kluwer Acadmic Publishers, Printed in the Netherlands, pp: $840-841$. 